\title{
Role of volcanic forcing on future global carbon cycle
}

\author{
J. F. Tjiputra ${ }^{1,3}$ and O. H. Otterå ${ }^{2,3}$ \\ ${ }^{1}$ Geophysical Institute, University of Bergen, Bergen, Norway \\ ${ }^{2}$ Uni Bjerknes Centre, Uni Research, Bergen, Norway \\ ${ }^{3}$ Bjerknes Centre for Climate Research, Bergen, Norway
}

Received: 8 February 2011 - Published in Earth Syst. Dynam. Discuss.: 16 February 2011

Revised: 6 June 2011 - Accepted: 6 June 2011 - Published: 16 June 2011

\begin{abstract}
Using a fully coupled global climate-carbon cycle model, we assess the potential role of volcanic eruptions on future projection of climate change and its associated carbon cycle feedback. The volcanic-like forcings are applied together with a business-as-usual IPCC-A2 carbon emissions scenario. We show that very large volcanic eruptions similar to Tambora lead to short-term substantial global cooling. However, over a long period, smaller eruptions similar to Pinatubo in amplitude, but set to occur frequently, would have a stronger impact on future climate change. In a scenario where the volcanic external forcings are prescribed with a five-year frequency, the induced cooling immediately lower the global temperature by more than one degree before it returns to the warming trend. Therefore, the climate change is approximately delayed by several decades, and by the end of the 21 st century, the warming is still below two degrees when compared to the present day period. Our climate-carbon feedback analysis shows that future volcanic eruptions induce positive feedbacks (i.e., more carbon sink) on both the terrestrial and oceanic carbon cycle. The feedback signal on the ocean is consistently smaller than the terrestrial counterpart and the feedback strength is proportionally related to the frequency of the volcanic eruption events. The cooler climate reduces the terrestrial heterotrophic respiration in the northern high latitude and increases net primary production in the tropics, which contributes to more than $45 \%$ increase in accumulated carbon uptake over land. The increased solubility of $\mathrm{CO}_{2}$ gas in seawater associated with cooler SST is offset by a reduced $\mathrm{CO}_{2}$ partial pressure gradient between the ocean and the atmosphere, which results in small changes in net ocean carbon uptake. Similarly, there is nearly no change in the seawater buffer capacity simulated between the different volcanic scenarios. Our study
\end{abstract}

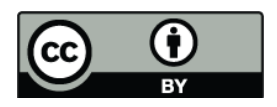

Correspondence to: J. F. Tjiputra (jtj061@uib.no) shows that even in the relatively extreme scenario where large volcanic eruptions occur every five-years period, the induced cooling leads to a reduction of $46 \mathrm{ppmv}$ atmospheric $\mathrm{CO}_{2}$ concentration as compared to the reference projection of $878 \mathrm{ppmv}$, at the end of the 21 st century.

\section{Introduction}

Future climate change is expected to vary considerably according to the rate of anthropogenic carbon emissions and uptake by both the ocean and the terrestrial biosphere. Earth system models, which contain interactions between the atmospheric and oceanic physics coupled with the global carbon cycle, are useful tools for predicting how future climate would evolve under a given anthropogenic greenhouse gas emission scenario. Recent studies using such models have indicated that future climate change will reduce the efficiency of the Earth system to absorb the emitted anthropogenic carbon, and would hence provide a positive feedback (Friedlingstein et al., 2006; Crueger et al., 2008; Tjiputra et al., 2010). Those studies, however, did not take into account not yet predictable factors such as volcanic eruptions or similar external forcings.

Volcanic forcing is well known to induce negative radiative forcing following the eruption events (Hansen et al., 1996; Gregory, 2010). Recent studies have also emphasized the crucial role of volcanic eruptions in controlling the global climate variability in the past (Stenchikov et al., 2009; Otterå et al., 2010). Explosive volcanic eruptions inject a large amount of different types of particles and gases into the stratosphere, such as ash, water vapour $\left(\mathrm{H}_{2} \mathrm{O}\right)$, carbon dioxide $\left(\mathrm{CO}_{2}\right)$, and sulfur dioxide $\left(\mathrm{SO}_{2}\right)$. Most of the ash will be washed out of the troposphere quite rapidly, on time scales of minutes to a few weeks. Gases such as $\mathrm{H}_{2} \mathrm{O}$ and $\mathrm{CO}_{2}$ are important greenhouse gases, but their atmospheric concentrations are so large that individual eruptions have a

Published by Copernicus Publications on behalf of the European Geosciences Union. 
minimal effect upon the overall concentrations and thus, do not directly impact the greenhouse effect.

The most important climatic effect of explosive volcanic eruptions is through the emission of sulphur species, mostly as $\mathrm{SO}_{2}$, into the stratosphere. The $\mathrm{SO}_{2}$ is rapidly converted into sulphuric acid, which in turn condenses into aerosols. These volcanic aerosols are then spread around the globe by atmospheric circulation and produce aerosol clouds that scatter more incoming solar radiation back to the space, resulting in cooler surface temperatures. In addition, volcanic aerosols also absorb both solar and terrestrial radiation, which heat the stratosphere (Robock, 2000). The resulting perturbation to the Earth's radiative balance, in turn, alters the atmospheric circulation and other climate parameters. However, the large reduction in direct short-wave radiation reaching the surface is the primary response of the volcanic aerosols resulting in a net surface and global cooling.

Sulfate aerosols resulting from strong volcanic explosions last for 3-5 years in the lower stratosphere. Therefore, it has traditionally been believed that volcanic impacts produce mainly short-term, transient climate perturbations. However, the ocean integrates volcanic radiative cooling and responds over a wide range of time scales. Some recent model studies indicate that very large eruptions or a clustering of major eruptions may represent a substantial climate forcing over decadal to multi-decadal time scales (Stenchikov et al., 2009; Ottera et al., 2010). In these studies key variables in the Atlantic climate system, such as sea ice and the ocean circulation are found to be quite sensitive to volcanic forcing. The associated processes, especially ocean heat uptake, play a key role in ongoing climate change. An improved assessment of possible long-term climate effects of volcanic eruptions is therefore important in order to put the ongoing climate change into a proper context.

By perturbing the climate system, volcanic eruption will alter the global carbon cycle as well. Studies by Sarmiento (1993) and Jones and Cox (2001) show a measurable change in the atmospheric $\mathrm{CO}_{2}$ concentration growth rate following the 1991 Mount Pinatubo eruption, which cannot be explained by the changes in anthropogenic carbon emissions alone. A further study by Bousquet et al. (2000) indicates an additional carbon sink of about $2 \mathrm{Pg} \mathrm{C}$ in response to the Pinatubo eruption. These changes are dominated by changes in the terrestrial carbon uptake predominantly due to the reduction in soil remineralization as a result of high latitude cooling following the eruption event.

In addition to the short term change in the terrestrial and oceanic carbon balance, the climate perturbation introduced by the volcanic forcings can also have a long term impact on the global carbon cycle, which introduce an additional feedback to the climate system. For example, in their probabilistic study coupled with an ensemble of proxy data, Frank et al. (2010) show a broad distribution of the climate sensitivity of the global carbon cycle over the preindustrial period. This large uncertainty is, to some extent, attributed to the short-term climate variability (e.g., volcanic eruptions) that is not detected from the proxy record, as also shown in Gerber et al. (2003). A study by Frölicher et al. (2011) indicates that short term volcanic forcings, depending on the forcing magnitude, plays an important role in altering the carbon cycle-climate sensitivity. They demonstrate that the change in atmospheric $\mathrm{CO}_{2}$ per unit change in global mean surface temperature decreases with increasing magnitude of the volcanic perturbation. For the historical period over the past few decades, other studies has also stated and emphasized the important roles of volcanic forcings in influencing the observed variability of the air-sea, air-land $\mathrm{CO}_{2}$ fluxes, and the airborne fraction of anthropogenic $\mathrm{CO}_{2}$ emissions (Le Quéré et al., 2009; Gloor et al., 2010; Sarmiento et al., 2010). This change in trends and variability could, in turn, further implicate and contribute to the uncertainties of the climate carbon cycle feedbacks, which is suggested to be an important element for the future model projections (Meehl et al., 2007). For the reasons mentioned above, it is therefore necessary to better understand the role of potential future volcanic forcings on the global carbon cycle to better interpret any uncertainties associated with future climate and carbon cycle projections.

Even though it is well established that volcanic forcings is important for the climate-carbon cycle sensitivity, most studies have so far focused only on analysing this sensitivity for the historical periods (e.g., Brovkin et al., 2010; Frölicher et al., 2011). Our study, to the authors' best knowledge, represents the first attempt to assess the role of volcanic forcings on the future carbon cycle and its respective feedback strength to the climate by using a comprehensive coupled climate-carbon cycle model. Here, we focus on understanding the role of pulse-like volcanic forcings under the business-as-usual, IPCC SRES-A2 future $\mathrm{CO}_{2}$ emissions scenario. We apply the future emissions scenario into the Bergen Earth system model (BCM-C), which consists of a fully interactive climate model coupled with interactive oceanic and terrestrial carbon cycle models. In addition to the reference run, three simulations adopting different future volcanic eruption scenarios are performed to better understand the role of magnitude and frequency of the eruption events. The spatial and temporal perturbation of the temperature and precipitation after the volcanic eruptions event are analyzed together with changes in sea-air and land-air carbon fluxes. Regional change in carbon inventory in both land and ocean reservoirs projected in the future are also assessed.

In addition to the above motivation, due to the counteracting effect of volcanic eruptions on anthropogenic climate change and atmospheric $\mathrm{CO}_{2}$ concentration, several geoengineering options for climate change mitigation mimicking the volcanic eruptions have been recently proposed and studied (e.g., Crutzen, 2006; Wigley, 2006; Rasch et al., 2008; Robock et al., 2008, 2010; Jones et al., 2009; Royal Society, 2009; Moore et al., 2010). However, the impact and feedback of such large-scale geoengineering schemes on the 
Earth system remain poorly understood. A more detailed assessment is therefore needed before one could even consider the method as promising or would have to reject it. Earth system models, such as the BCM-C, offer the ideal laboratory to perform such sulfur injection schemes in a controlled environment, and systematically assess potential impacts on climate and environment. Therefore, this study will also improve our understanding how the Earth system, particularly how the global carbon cycle may be influenced by stratospheric sulphur injection type geoengineering mitigation.

The paper is organized as follows: the next section will describe the model and experiment design adopted in this study. The third section will discuss our experiment results in regards to the global climate sensitivity and changes to the terrestrial and oceanic carbon cycles. The final section includes a discussion and a summary of the paper.

\section{Method}

\subsection{Model description}

The Bergen Earth system model (BCM-C) used in this study is an updated version of the Bergen Climate Model (BCM; Furevik et al., 2003) coupled with terrestrial and oceanic carbon cycle models. The atmospheric component is ARPEGEClimat version 3 with a truncation at wave number 63 (TL63) and $1800 \mathrm{~s}$ time step. A total of 31 vertical levels, ranging from the surface to $0.01 \mathrm{hPa}$ are employed. The current version differs from the original BCM in that the vertical diffusion scheme has been updated to that of ARPEGE-Climat version 4 (Otterå et al., 2009). The ocean component is a modified version of MICOM (Bleck and Smith, 1990; Bleck et al., 1992; Bentsen et al., 2004), an isopycnic ocean GCM. It has approximately $2.4^{\circ} \times 2.4^{\circ}$ horizontal resolution with 34 isopycnic vertical layers. The model adopts a single nonisopycnic surface mixed layer, which provides the linkage between the atmospheric forcing and the ocean interior. The ocean carbon cycle model is the Hamburg oceanic carbon cycle (HAMOCC5) model (Maier-Reimer et al., 2005). The HAMOCC5 model simulates carbon chemistry and includes an NPZD-type (nutrient, phytoplankton, zooplankton, and detritus) ecosystem model. The terrestrial carbon model is the Lund-Potsdam-Jena (LPJ) model (Sitch et al., 2003). The LPJ is a large-scale dynamic vegetation model and contains 10 plant functional types. A more detailed description of the BCM-C model and its evaluation are available in Tjiputra et al. (2010).

In all simulations, the BCM-C is interactively coupled with the carbon cycle modules with no flux adjustments applied. In order to simulate volcanic eruptions, sulphur aerosols are injected directly into the stratosphere. Note that the model does not have an interactive aerosol scheme. Thus, for each volcanic scenario experiment, we applied different atmospheric boundary condition to the model where the optical properties of the atmospheric aerosols is modified according to the different magnitude and frequencies of volcanic eruption. The volcanic aerosol time series is supplied as monthly optical depths at 0.55 microns, in the middle of the visible spectrum (Crowley et al., 2003). The forcing were applied as quarterspheric $\left(30^{\circ} \mathrm{N}-90^{\circ} \mathrm{N}, 0-30^{\circ} \mathrm{N}, 30^{\circ} \mathrm{S}-0\right.$, $90^{\circ} \mathrm{S}-30^{\circ} \mathrm{S}$ ) monthly values, and distributed in each model level in the stratosphere (Otterå, 2008). The volcanic mass of the stratospheric aerosols are calculated at each grid point and model level in the stratosphere by dividing the total aerosol concentration by the total air mass of all stratospheric levels at that grid point.

The atmosphere model ARPEGE (i.e., the atmospheric component of the BCM-C) is able to reproduce many of the observed features after the Mount Pinatubo eruption (Otterå, 2008). Both the simulated short-wave and long-wave reductions as well as the general global cooling after the eruption compares favourably with observations. In addition, the observed winter warming pattern over NH land is well captured. This winter warming was caused by an anomalously positive phase of the Arctic Oscillation (AO) associated with the enhanced Equator-to-pole temperature gradient in the stratosphere that developed due to aerosol heating of the tropics. Similarly, the opposite summer cooling observed is also produced by the model. Finally, a strong response of the AO/NAO to historical volcanic forcing in BCM (i.e. in coupled mode) has been further confirmed in a long transient simulation of the last 600 years (Otterå et al., 2010).

\subsection{Experiment design}

To validate the model capacity in simulating the expected changes associated to the volcanic forcing perturbation, we performed two historical period simulations (1989-2001). In the first simulation, the model is forced only by the observed $\mathrm{CO}_{2}$ emissions (the same with experiment REF described below), whereas the second simulation includes the Pinatubo eruption forcing introduced in the year 1991. The 1991 Mount Pinatubo eruption forcing is taken from historical data set of Crowley et al. (2003).

Next, a total of four future scenario model simulations are performed with the BCM-C model. Note that prior to all model simulations, the model has been spun up for more than 1000-years based on constant preindustrial atmospheric $\mathrm{CO}_{2}$ concentration of $284.7 \mathrm{ppmv}$. Afterwards, the fully coupled model is simulated from year 1850 to 2019 forced only by prescribed historical and the SRES-A2 $\mathrm{CO}_{2}$ emission time series (Marland et al., 2005; Houghton and Hackler, 2002). The model is then branched out into four separate simulations, while still prescribing the A2 emissions scenario toward the end of the 21 st century.

In the first branch, no external forcing is applied, hence it serves as a reference simulation, REF. Next, we select two historical volcanic eruptions from the volcanic forcing data 


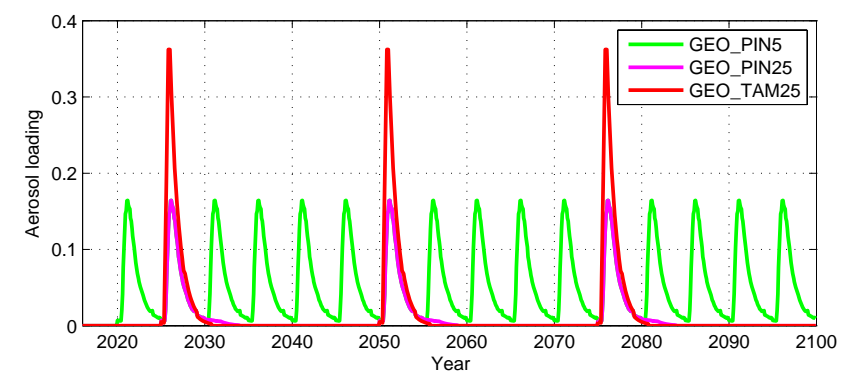

Fig. 1. Mean global change in aerosol loading (optical depth at $0.55 \mu \mathrm{m}$ ) applied to simulate the volcanic forcings in the GEO_TAM25, GEO_PIN25, and GEO_PIN5 experiments.

set of Crowley et al. (2003) and construct three alternative scenarios based on different magnitudes and frequencies. In the second branch, a volcanic eruption corresponding to the Tambora 1815 historical eruption is applied in 25-year intervals, starting from year 2025, GEO_TAM25. In the third branch a relatively weaker magnitude of volcanic eruption corresponding to the 1991 Mount Pinatubo eruption is applied, also in 25-year intervals from year 2025, GEO_PIN25. Finally, in the fourth branch, the Pinatubo-like volcanic eruptions are applied again, but with higher frequency of 5-year intervals, starting from year 2020, GEO_PIN5. Figure 1 illustrates the modification in the aerosol loading applied in experiments GEO_TAM25, GEO_PIN25, and GEO_PIN5, shown as change in monthly optical depths at 0.55 microns, in the middle of the visible spectrum. Table 1 summarizes the descriptions of all three model simulations together with the integrated change in optical depth (aerosol loadings) added into each volcanic scenario. This change in aerosol optical depth properties, in turn, alters the incoming short-wave (SW) and emitted long-wave (LW) radiative fluxes at the top of the atmosphere simulated by the atmospheric model in the BCM-C model.

Note that natural volcanic eruptions also release greenhouse gases such as $\mathrm{H}_{2} \mathrm{O}$ and $\mathrm{CO}_{2}$, but both in negligible amounts compared to the associated concentrations in the current atmosphere. Thus, only sulfur aerosols are included in this study. The BCM-C future projection and climatecarbon cycle feedback under the SRES-A2 have been evaluated and is well within the range of other models (Friedlingstein et al., 2006; Tjiputra et al., 2010).

\section{Results}

For the present day simulation, Fig. 2 shows that the model simulates a reduction in the global surface temperature following the 1991 Pinatubo eruptions, which lasts for some years before returning to the reference value (i.e., as the run without the Pinatubo eruption). In addition to the aerosolassociated atmospheric cooling, the simulated atmospheric
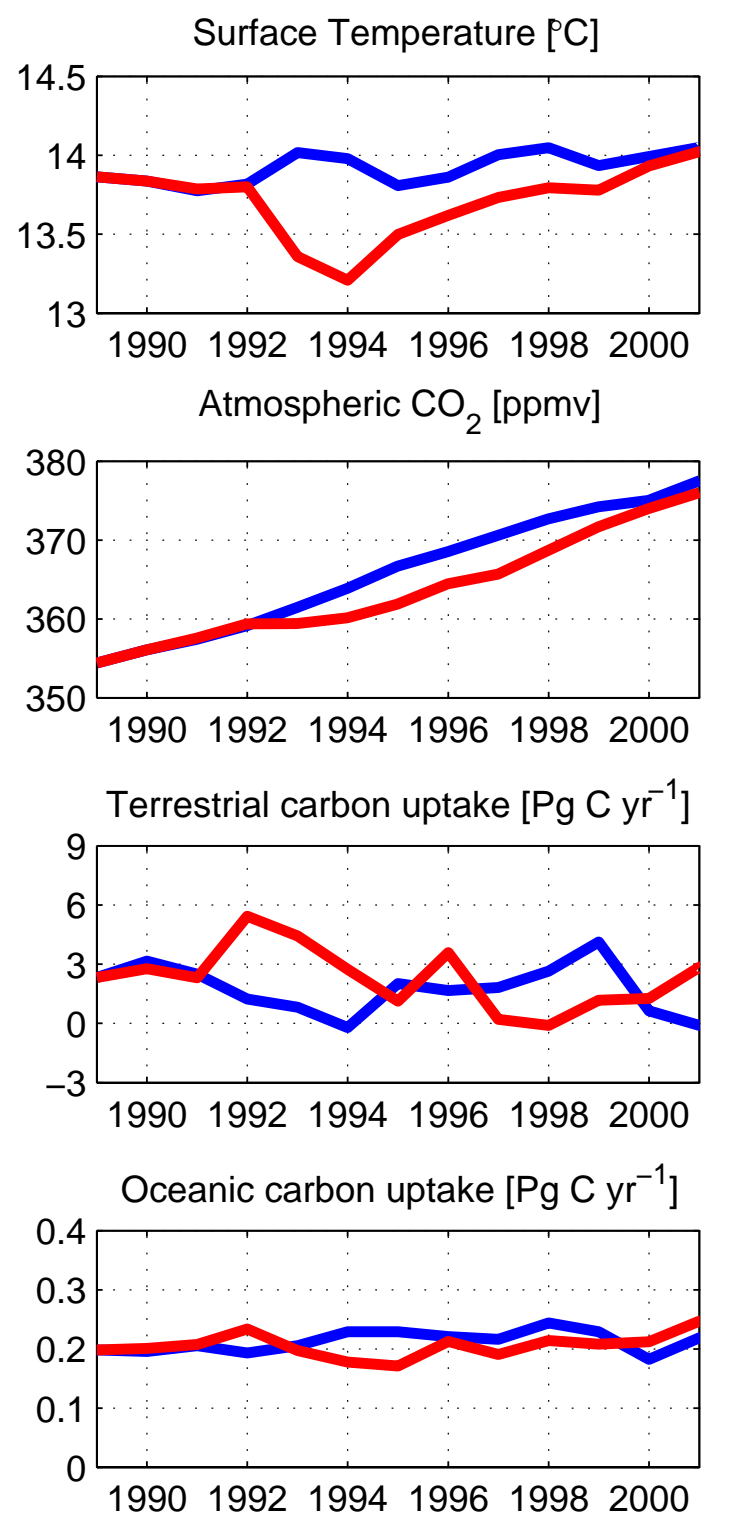

Fig. 2. Time series of global mean surface temperature, atmospheric $\mathrm{CO}_{2}$ concentration, terrestrial and oceanic carbon uptake for the 1989-2001 period. Shown here are two simulations, with (red lines) and without (blue lines) the 1991 Mount Pinatubo eruption.

$\mathrm{CO}_{2}$ concentration is also reduced by as much as $4.95 \mathrm{ppmv}$ relative to the simulation with no Pinatubo in the years after the eruptions. Note that the dominant increasing trend of atmospheric $\mathrm{CO}_{2}$ concentration in the 1990 s period persists, as shown in Fig. 2. The reduction in the atmospheric $\mathrm{CO}_{2}$ is predominantly associated to the stronger terrestrial carbon uptake immediately following the Pinatubo eruption. The change in oceanic carbon uptake signals is less pronounced, with a slight increase in the beginning followed by less carbon uptake periods as compared to the simulation without the Pinatubo eruption. This less oceanic carbon uptake is attributed to the smaller atmospheric-ocean $\mathrm{CO}_{2}$ gradient as 
Table 1. List of the performed experiments with the period of integrations, $\mathrm{CO}_{2}$ emissions, volcanic frequencies, and the integrated change in aerosol optical depth for each volcanic scenario.

\begin{tabular}{lclll}
\hline Experiment & Period & $\mathrm{CO}_{2}$ emissions & Volcanic frequency & Aerosol loading \\
\hline REF & $1850-2099$ & Historical, IPCC-A2 & none & none \\
HIST_PIN & $1989-2001$ & Historical & once (1991) & 3.6410 \\
GEO_TAM25 & $2020-2099$ & IPCC-A2 & 25-year (from 2025) & 18.4819 \\
GEO_PIN25 & $2020-2099$ & IPCC-A2 & 25-year (from 2025) & 10.9229 \\
GEO_PIN5 & $2020-2099$ & IPCC-A2 & 5-year (from 2020) & 54.7848 \\
\hline
\end{tabular}
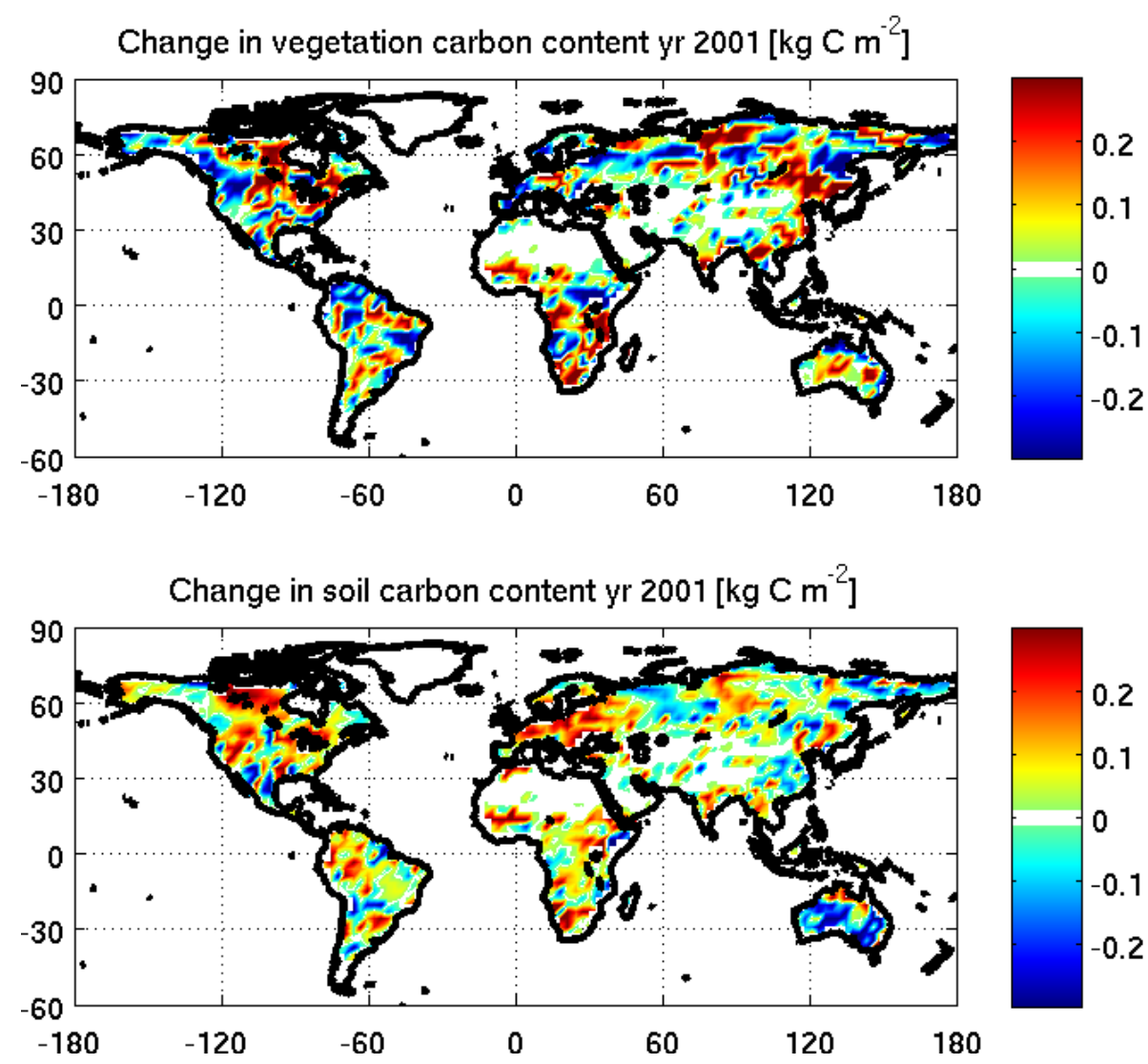

Fig. 3. Regional change in (top) vegetation and (bottom) soil carbon content due to the Mount Pinatubo eruptions computed at year 2001.

a result of stronger terrestrial carbon uptake. The simulated changes in temperature, atmospheric $\mathrm{CO}_{2}$ concentration, and carbon uptakes are broadly consistent with earlier studies (Sarmiento, 1993; Bousquet et al., 2000; Lucht et al., 2002; Angert et al., 2004). The increase in terrestrial carbon uptake in our model is dominated by the reduction in the heterotrophic respiration due to cooler climate. This is shown by the increase in high latitude soil carbon content simulated at year 2001, ten years after the Pinatubo eruption, as shown in Fig. 3. However, the change in vegetation carbon is more complicated, with opposite signals (increase and reduction) occurring in both low latitude and high latitude regions.
In the future scenario simulations, the volcanic forcing induces cooler surface temperatures immediately following the perturbation. The largest cooling is simulated over high latitudes, particularly the Northern Hemisphere, which results in an enhanced pole-to-equator temperature gradient. In GEO_TAM25, the volcanic forcings induce an average of approximately one degree cooling in the simulated global mean surface temperature immediately follow the eruption events. Similar cooling patterns, which are followed by rapid warming, are also generated in the sea surface temperature. Figure 4 shows that the cooling effect in GEO_TAM25 only lasts for a few years before the air and SST temperatures return to the expected warming trends as seen in REF. 
As expected, the simulated short-term cooling effect is weaker in GEO_PIN25 than in GEO_TAM25. However, when the frequency of volcanic forcings is increased, GEO_PIN5, the short-term cooling associated with the first few volcanic events accumulate and the overall persisted warming trend is delayed by several decades. Figure 4 also shows that the warming rate in GEO_PIN5 is not as sharp as in the REF with the simulated global air temperature being approximately one degree lower.

Similar to the temperature, the global mean precipitation also undergoes changes. As a result of a reduction in incoming SW radiation, the model simulates global reductions in evaporation and atmospheric water vapor content (not shown), thus decreasing the global precipitation. Similar to the temperature signals, the short-term reduction in global precipitation is strongest in the GEO_TAM25 run. Interestingly, by the end of the 21st century, GEO_PIN5 simulates relatively small changes in global precipitation relative to the period before the volcanic forcings are introduced (i.e., year 2019), despite the fact that considerable changes in SST and air temperature are predicted. Figure 4 also illustrates that in GEO_TAM25, GEO_PIN25, and GEO_PIN5 the Arctic sea ice extent and the Atlantic Meridional Overturning Circulation (AMOC) are expected to decrease toward the end of the experiment period, closely following the REF simulation. Again, the GEO_PIN5 simulates the least reduction by the end of the experiment period.

With regards to the global carbon cycle, there are noticeable increases in both the oceanic and terrestrial carbon uptakes following the volcanic events in GEO_TAM25 as compared to the REF. Nevertheless, REF, GEO_TAM25, and GEO_PIN25 all project virtually the same atmospheric $\mathrm{CO}_{2}$ concentration by the end of the 21 st century (Fig. 5). Figure 5 also indicates that the volcanic-like forcings induce temporary increases in oceanic and terrestrial carbon uptakes, with the land uptake being more pronounced. The terrestrial and oceanic carbon uptakes simulated by GEO_PIN25 generally resemble that of GEO_TAM25, but with weaker amplitudes.

In the GEO_PIN5, the volcanic forcings induce a more pronounced change in the terrestrial carbon uptake than the oceanic counterpart. For the 2020 to 2099 period, the model simulates accumulated oceanic and land carbon uptake of 373.1 and 313.5 Pg C, as compared to 377.0 and 215.9 Pg C simulated in REF (see also Table 2). Therefore, to a first order, an increase in terrestrial carbon uptake in GEO_PIN5 could explain the simulated $45.6 \mathrm{ppmv}$ lower atmospheric $\mathrm{CO}_{2}$ concentration at the end of the 21 st century (i.e., difference in terrestrial carbon uptake of $97.6 \mathrm{Pg} \mathrm{C}$ approximately corresponds to $46.7 \mathrm{ppmv}$ ).

In the next subsection, we will attempt to quantify the global climate sensitivity, carbon feedback associated to the volcanic forcings, and analyze the post-eruption changes. Due to the relatively small changes simulated in GEO_TAM25 and GEO_PIN25 compare to REF,
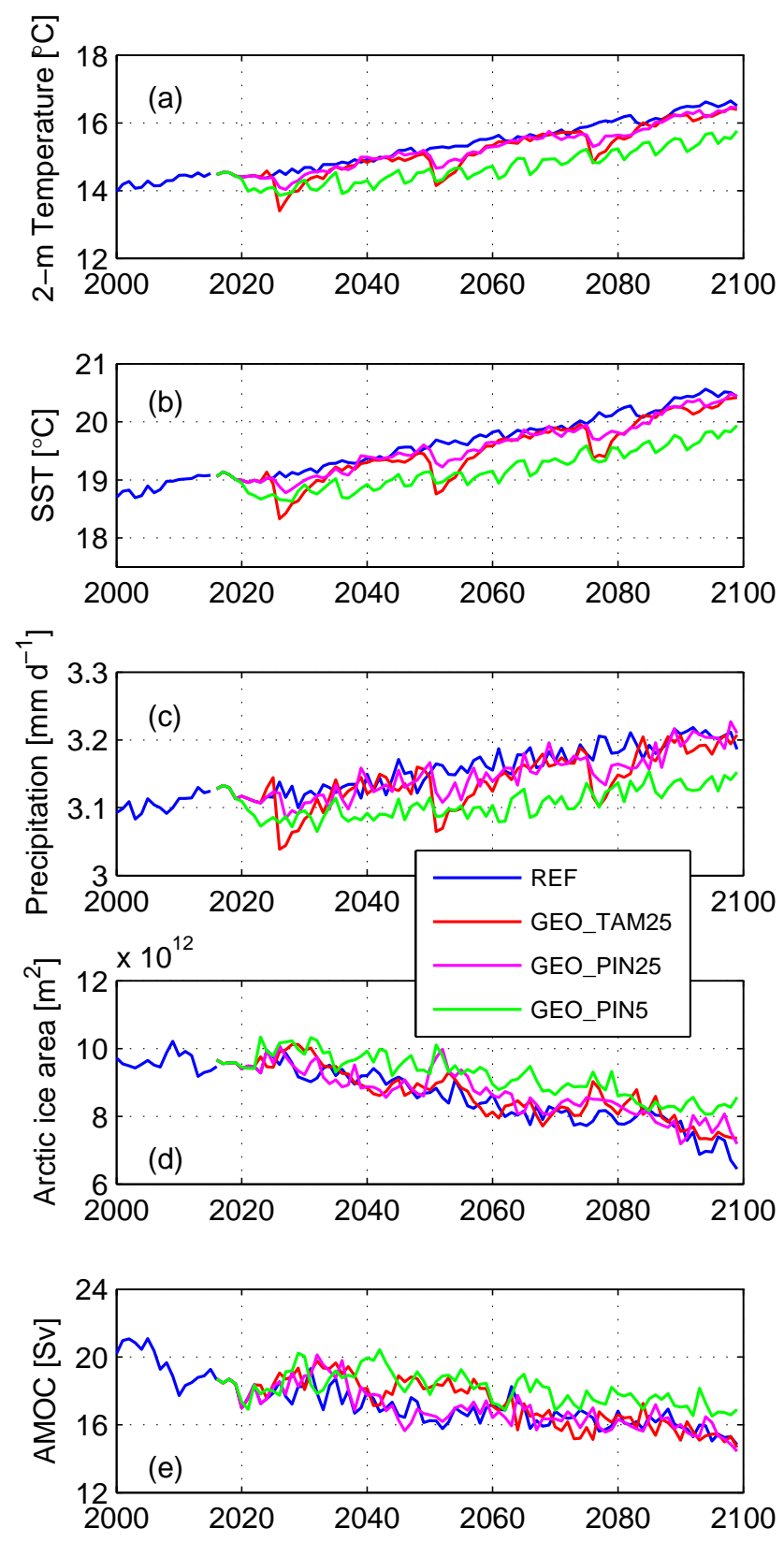

Fig. 4. Model projection of global mean (a) 2-m surface air temperature, (b) sea surface temperature, (c) precipitation, (d) summer (September) Arctic sea ice area, and (e) Atlantic Meridional Overturning Circulation (AMOC) strength for each experiments.

our post-eruption analysis will be focused more on the GEO_PIN5 results.

\subsection{Climate sensitivity and carbon feedback}

Here, we analyze the role of volcanic eruptions, focusing on the aerosol loading added to the atmosphere, in changing the global temperature and carbon uptake. For the period of 2020-2099, experiment REF simulated a change in 
Table 2. Simulated change in global mean temperature $(\Delta T)$, atmospheric $\mathrm{CO}_{2}$ concentration $\left(\Delta C_{\mathrm{A}}\right)$, oceanic $\left(\Delta C_{\mathrm{O}}\right)$ and terrestrial $\left(\Delta C_{\mathrm{L}}\right)$ carbon content, and residual carbon uptake $\left(R_{\mathrm{O}}\right.$ and $\left.R_{\mathrm{L}}\right)$ computed over the 2020-2099 period.

\begin{tabular}{lccccrr}
\hline Experiment & $\Delta T\left[{ }^{\circ} \mathrm{C}\right]$ & $\Delta C_{\mathrm{A}}[\mathrm{ppmv}]$ & $\Delta C_{\mathrm{O}}[\mathrm{PgC}]$ & $\Delta C_{\mathrm{L}}[\mathrm{PgC}]$ & $R_{\mathrm{O}}[\mathrm{PgC}]$ & $R_{\mathrm{L}}[\mathrm{PgC}]$ \\
\hline REF & 2.10 & 454.30 & 377.03 & 215.88 & 0.00 & 0.00 \\
GEO_TAM25 & 1.99 & 446.13 & 377.11 & 230.15 & 5.22 & 10.10 \\
GEO_PIN25 & 2.04 & 444.81 & 375.77 & 235.90 & 6.25 & 22.73 \\
GEO_PIN5 & 1.42 & 408.73 & 373.09 & 313.48 & 23.25 & 66.95 \\
\hline
\end{tabular}
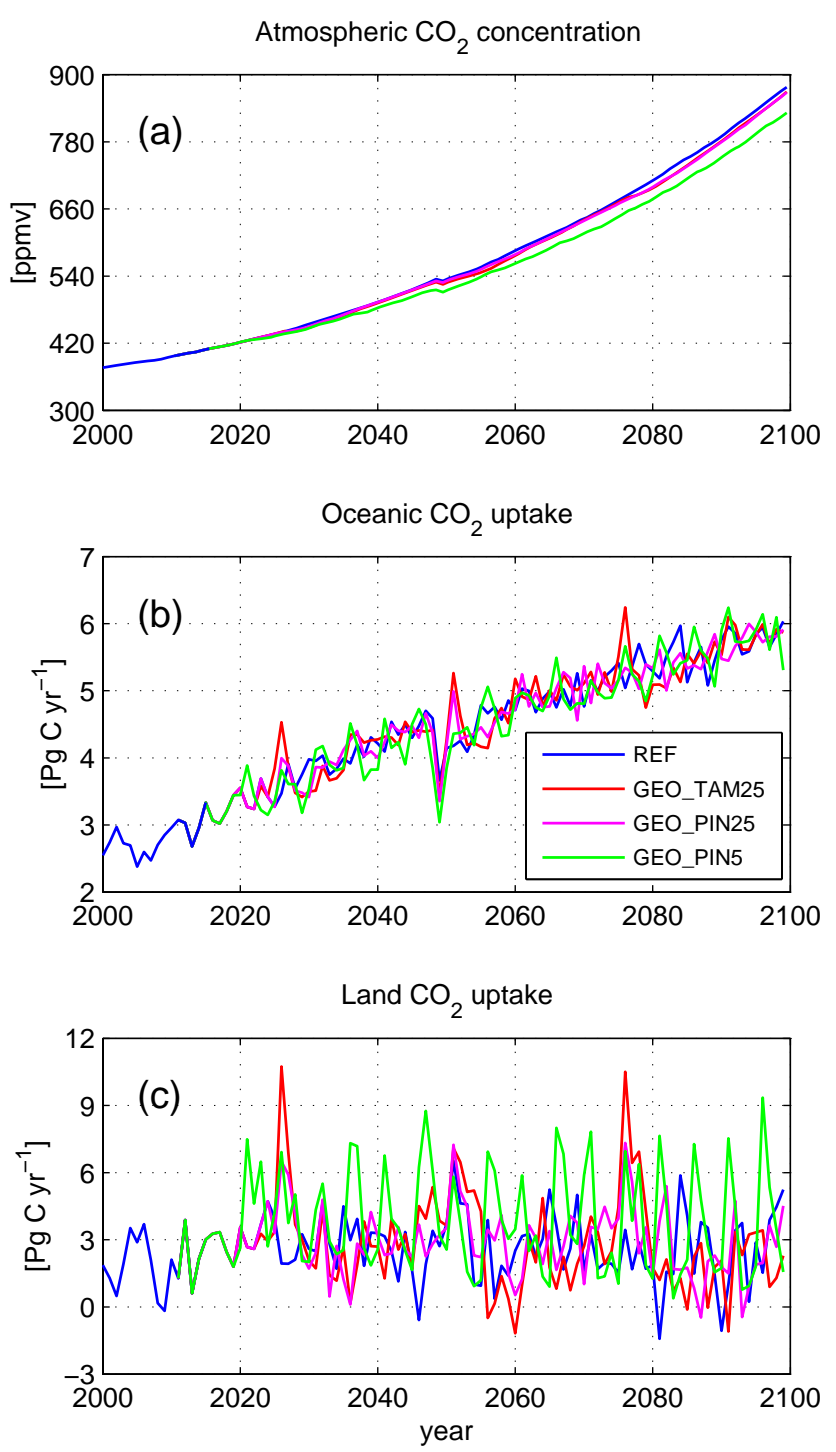

Fig. 5. Model projection of annual mean (a) atmospheric $\mathrm{CO}_{2}$ concentration, (b) oceanic carbon uptake, and (c) terrestrial carbon uptake over the 2000-2099 period. global mean temperature and atmospheric $\mathrm{CO}_{2}$ of $2.1^{\circ} \mathrm{C}$ and 454.3 ppmv, respectively. These quantities yield a climate sensitivity of $0.0046^{\circ} \mathrm{Cppmv}^{-1}$ for the BCM-C model over the studied period. The value is reasonable and well within the range of the other Earth system models of 0.0038 $0.0082^{\circ} \mathrm{C} \mathrm{ppmv}^{-1}$ (Friedlingstein et al., 2006). Table 2 summarizes the change in global mean temperature and carbon content in the atmosphere, ocean, and land for each volcanic scenario simulation over the 2020-2099 period. Multiplying the climate sensitivity above with the change in atmospheric $\mathrm{CO}_{2}$ concentration yields the expected change in temperature of $2.05,2.05$, and $1.88^{\circ} \mathrm{C}$ for the three volcanic scenario simulations. Therefore, by the end of experiment period, the aerosol loading added into the GEO_TAM25, GEO_PIN25, and GEO_PIN5 experiments lead to additional cooling of $0.06,0.01$, and $0.46{ }^{\circ} \mathrm{C}$, respectively. While this suggests that the aerosol loading indeed induce cooling to the global temperature, over a long period, the effect is generally small, except for the case when large volcanic eruptions occur very frequent (i.e., GEO_PIN5).

The volcanic forcings also induce changes in both the oceanic and terrestrial carbon content. Following Friedlingstein et al. (2006), the change in oceanic and terrestrial carbon uptake due to change in temperature and atmospheric $\mathrm{CO}_{2}$ concentration can be estimated as follows:

$\Delta C_{\mathrm{O}}^{i}=\beta_{\mathrm{O}} \Delta C_{\mathrm{A}}^{i}+\gamma_{\mathrm{O}} \Delta T^{i}+R_{\mathrm{O}}^{i}$,

$\Delta C_{\mathrm{L}}^{i}=\beta_{\mathrm{L}} \Delta C_{\mathrm{A}}^{i}+\gamma_{\mathrm{L}} \Delta T^{i}+R_{\mathrm{L}}^{i}$,

where $\Delta C$ represents change in carbon inventory in atmosphere (A), ocean (O), and land (L) for each experiment $i$. Here, we include residual terms $\left(R_{\mathrm{L}}^{i}\right.$ and $\left.R_{\mathrm{O}}^{i}\right)$, which represent the change in land and oceanic carbon inventory attributed to the volcanic eruption forcing in each scenario. For the period of 2020-2099, the sensitivity of ocean and land carbon storage to change in atmospheric $\mathrm{CO}_{2}\left(\beta_{\mathrm{O}} / \beta_{\mathrm{L}}\right)$ computed from experiments in Tjiputra et al. (2010) are equal to 0.9346 and $0.9903 \mathrm{Pg} \mathrm{Cppmv}^{-1}$, respectively. Similarly the change in ocean and terrestrial carbon content to temperature change $\left(\gamma_{\mathrm{O}} / \gamma_{\mathrm{L}}\right)$ are equal to -22.6470 and $-111.4349 \mathrm{Pg} \mathrm{C}^{\circ} \mathrm{C}^{-1}$, respectively. The sensitivity numbers above are within the range of other Earth system models 

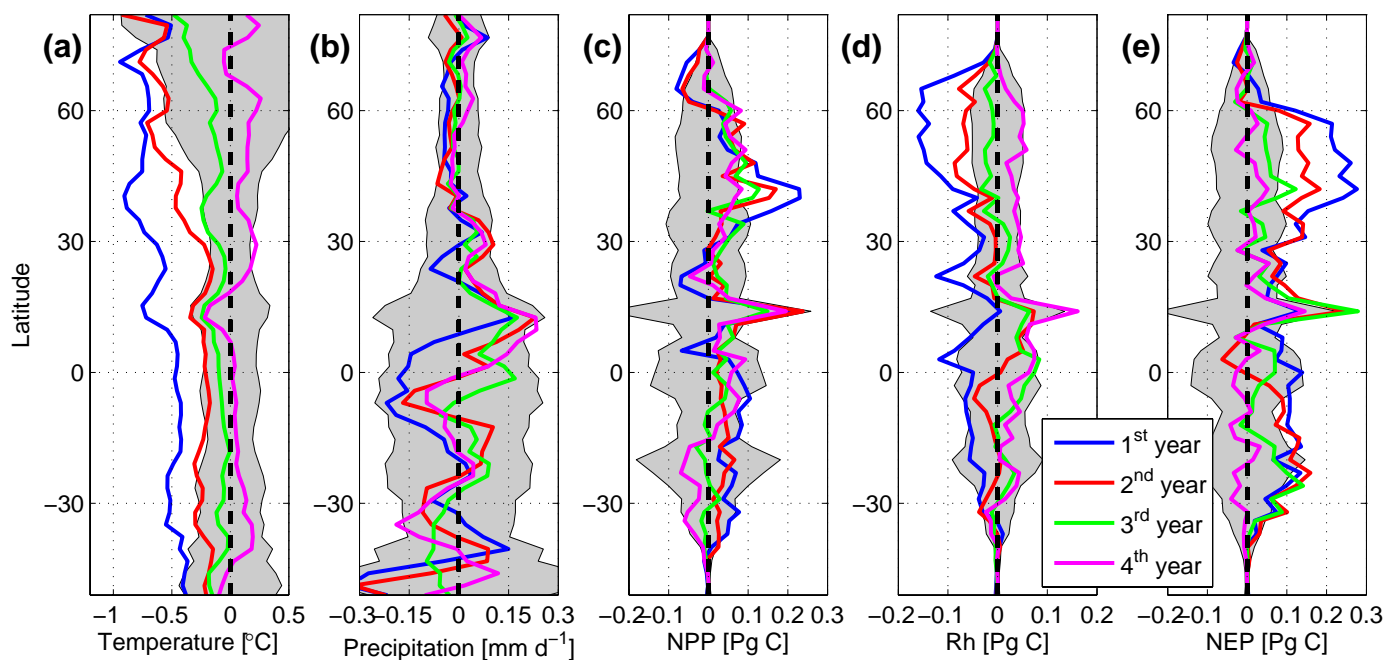

Fig. 6. Latitudinal change in annual mean (a) temperature, (b) precipitation, (c) net primary production, (d) heterotrophic respiration, and (e) net ecosystem production over land following the volcanic eruption forcing in GEO_PIN5. Colors represent different years immediately follow the eruptions. Both the temperature and precipitation change are computed only for land grid points. The grey shading represents the plus minus one-standard deviation of the year-to-year variability of each variable to indicate whether or not the signals are detectable.

given by Friedlingstein et al. (2006). Inserting these number to Eqs. (1) and (2) yield the oceanic and terrestrial residual terms for each experiment as summarized in Table 2 . Table 2 suggests that the volcanic forcings in all volcanic simulations induce positive feedback on the oceanic and terrestrial carbon cycle (i.e., more carbon uptake). The largest terrestrial residual term is simulated in GEO_PIN5, where the land takes up approximately additional $66.95 \mathrm{Pg}$ C. Experiment GEO_TAM25 yield the smallest increase in terrestrial carbon uptake of $10.10 \mathrm{PgC}$. The difference in the terrestrial residual terms are not obvious. For example, despite having more aerosol loading (see Table 1), GEO_TAM25 simulates smaller residual term than GEO_PIN25. While the ocean demonstrates relatively small change in accumulated carbon uptake in all experiments, the oceanic residual terms also show distinct variations. For example, an additional uptake of 23.25 Pg C is simulated in the GEO_PIN5, whereas only $6.25 \mathrm{Pg} \mathrm{C}$ is simulated in GEO_PIN25, suggesting that the frequency of the volcanic events is of importance.

\subsection{Terrestrial carbon cycle}

Fluxes of carbon between the atmosphere and the land are primarily controlled by the difference between terrestrial photosynthesis (uptake) and heterotrophic respiration (outgassing). In order to analyze the regional change in climate and carbon cycle over land associated with the eruptions, we compute the latitudinal mean change in land surface air temperature, precipitation, net primary production (NPP), soil respiration, and net ecosystem production $(\mathrm{NEP}=\mathrm{NPP}-$ respiration - fire emissions) in the first, second, third, and fourth years after the volcanic events
(Fig. 6). The mean deviation shown in Fig. 6 is computed from all 16 eruption events in GEO_PIN5 as compared to the year prior to each eruptions. Latitudinal change in precipitation is well within the standard deviation, suggesting that regional change in precipitation is generally not significant. However, change in the temperature in the first and second years show relatively large cooling signals. Changes in terrestrial carbon parameters appear to be detectable only in high latitudes. The largest mean cooling period occurs immediately following the volcanic eruption (i.e., first year) with a mean reduction of nearly $1{ }^{\circ} \mathrm{C}$ simulated in some regions in the Northern Hemisphere. Afterwards the temperature steadily recovers to the pre-eruption level. This is consistent with study by Brovkin et al. (2010), which also demonstrates a pronounced cooling over high latitude Northern Hemisphere landmasses. Also similar to their study, the BCM-C only simulates a small cooling in the Southern Hemisphere, essentially caused by the distinct land and ocean distribution between the two hemispheres.

Over the period when the volcanic forcings are applied, GEO_PIN5 simulates NPP and soil respiration reduction of approximately 27.7 and $122.8 \mathrm{PgC}$ as compared to the REF run. GEO_PIN5 also simulates slightly less accumulated carbon outgassing associated with fire fluxes of $2.4 \mathrm{Pg} \mathrm{C}$. This strongly reduced respiration more than offsets the reduced NPP and essentially leads to increased net terrestrial carbon uptake of about $97.5 \mathrm{Pg} \mathrm{C}$. By the end of the model simulation, the LPJ simulates increases in soil, litter and vegetation carbon masses by approximately $34.6,13.8$, and $48.8 \mathrm{Pg} \mathrm{C}$, respectively in GEO_PIN5 when compared to REF.

The net carbon gain by the terrestrial biosphere occurs mostly in the tropics and mid-latitude Northern Hemisphere. 

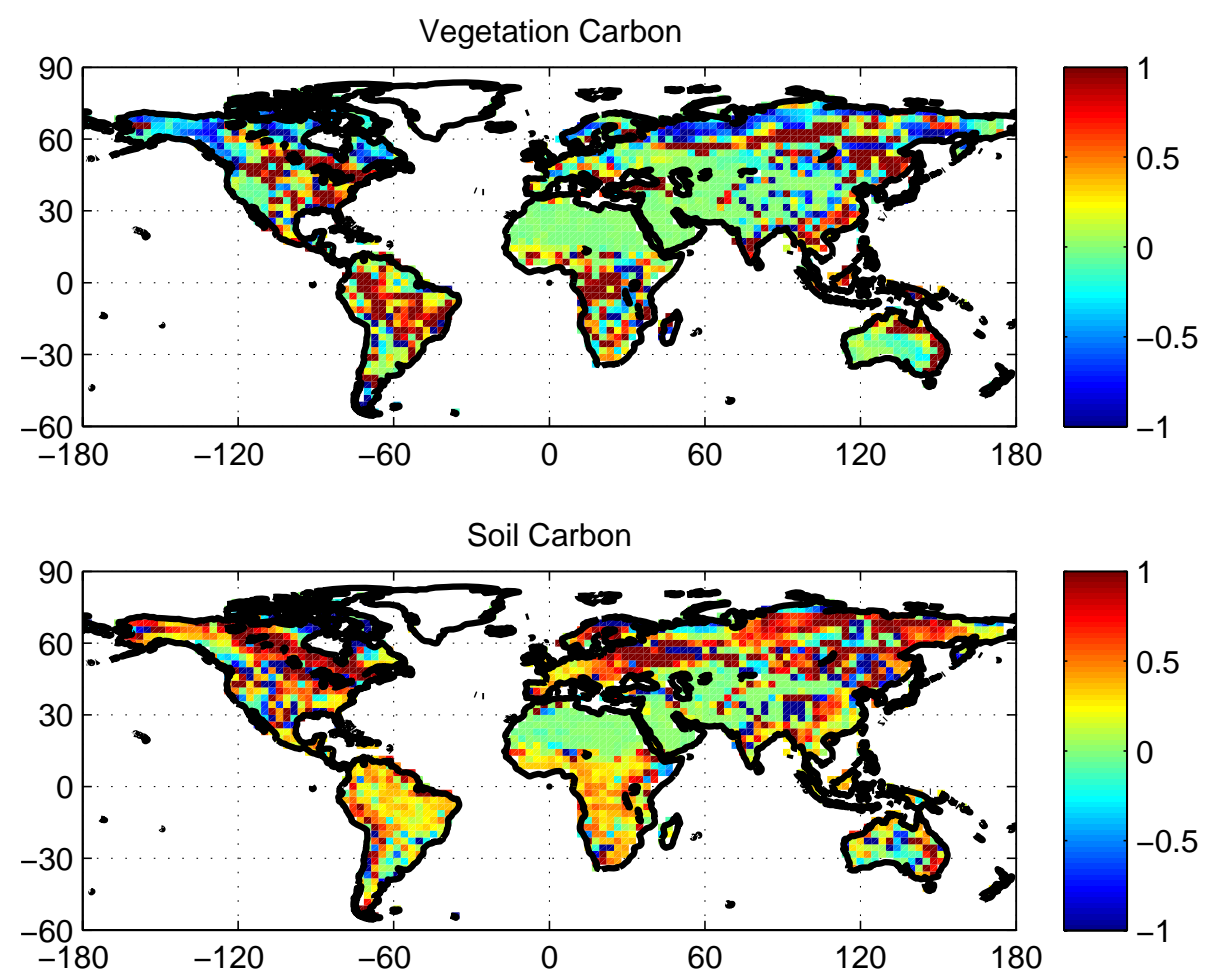

Fig. 7. Mean changes (GEO_PIN5 minus REF) in total land (top) vegetation and (bottom) soil carbon content due to additional volcanic forcings computed over 2090-2099 period. Units are in $\left[\mathrm{Kg} \mathrm{C} \mathrm{m}^{-2}\right]$.

We attribute the former to the increase in net primary production as shown in Fig. 6. On the other hand, the net carbon gain in the mid-latitude Northern Hemisphere is dominated by reduced soil respiration due to the simulated cooler temperatures following the eruption events. An earlier modeling study by Jones and Cox (2001) features similar mechanisms in the tropics associated with the Mount Pinatubo eruption. Figure 7 shows that the net primary production increase in the tropics leads to an increase in carbon stored in the vegetation pool, whereas reduced respiration in the midand high-latitude Northern Hemisphere lead to an increased soil carbon pool in these regions.

\subsection{Oceanic carbon cycle}

The global carbon uptake by the ocean is not perturbed substantially by the volcanic eruption forcings. Over the 2020 2099 period, experiments REF, GEO_TAM25, GEO_PIN25, and GEO_PIN5 simulate accumulated oceanic carbon uptake of 377.0, 377.1, 375.8 and 373.1 Pg C, respectively. Nevertheless, regional changes would be expected as a result of changing climate. In the model, the carbon fluxes from the atmosphere to the ocean are formulated as a function of solubility, gas transfer rate, and difference in atmospheric and oceanic partial pressure $\mathrm{CO}_{2}\left(p \mathrm{CO}_{2}\right)$ following Wanninkhof (1992). Thus changes in atmospheric circulation and temperature would alter the solubility and gas transfer rate parameters in the model, whereas changes in terrestrial carbon fluxes would, in addition, contribute to an altered air-sea $p \mathrm{CO}_{2}$ gradient. Changes in the gas transfer rate turns out to be relatively small compared to changes in the solubility (not shown). Figure 8 shows that the solubility of $\mathrm{CO}_{2}$ gas in seawater is expected to steadily decrease toward the end of the 21 st century for all ocean regions, based on experiment REF. Cooling effects associated with volcanic eruptions in both the GEO_TAM25 and GEO_PIN25 can clearly be detected, increasing the solubility temporarily for a few years following the eruptions before returning to the decreasing trend as in REF. In GEO_PIN5, more frequent volcanic forcings are able to increase and maintain a high solubility until the mid21 st century before they start to decrease. Interestingly, in the high latitude Southern Ocean, the solubility parameter appears to recover towards the end of experiment period.

Despite the delayed solubility reduction simulated in GEO_PIN5, there is no significant increase in global oceanic carbon uptake (see also Fig. 5). In fact, GEO_PIN5 simulates approximately $4 \mathrm{PgC}$ less uptake than the REF. We attribute this to the reduction in the atmospheric $\mathrm{CO}_{2}$ concentration, associated with a stronger carbon uptake by the terrestrial reservoir. This lower atmospheric $\mathrm{CO}_{2}$ concentration reduced the $p \mathrm{CO}_{2}$ gradient between the ocean and atmosphere, thus weakening the oceanic uptake strength.

Another way to explain the relatively small change in the oceanic carbon uptake to the volcanic forcings is through 


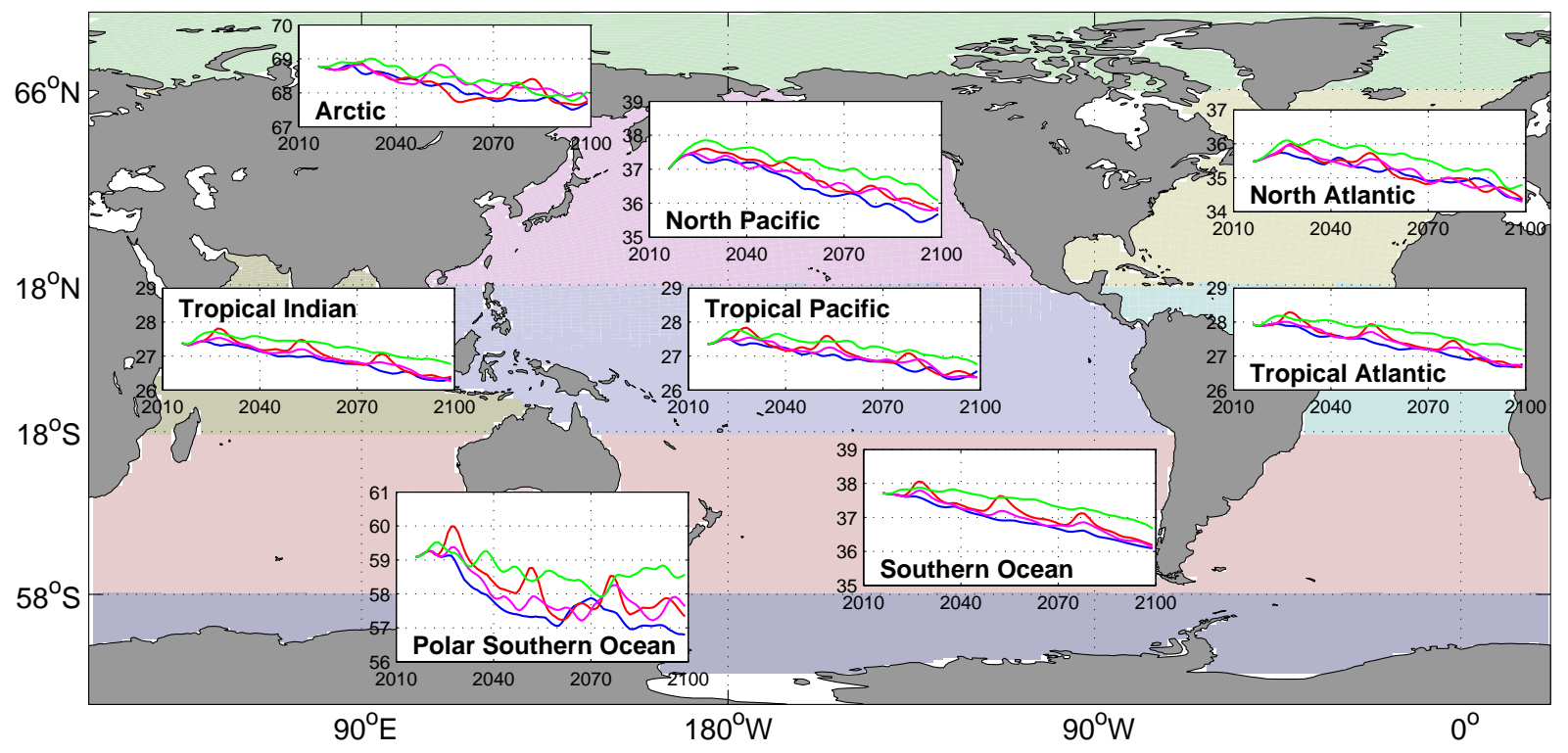

Fig. 8. Regional evolution of $\mathrm{CO}_{2}$ gas solubility in seawater from 2020 to 2099 period. Plotted here are the five-year running means from (blue-lines) REF, (red-lines) GEO_TAM25, (magenta-lines) GEO_PIN25, and (green-lines) GEO_PIN5 experiments. Units are in $\left[\mathrm{mmoll}^{-1} \mathrm{ppm}^{-1}\right]$. Regions are defined as follow: Arctic $\left(>66^{\circ} \mathrm{N}\right)$, North Atlantic $\left(18^{\circ} \mathrm{N}-66^{\circ} \mathrm{N}\right)$, North Pacific $\left(18^{\circ} \mathrm{N}-66^{\circ} \mathrm{N}\right)$, Tropical Atlantic $\left(18^{\circ} \mathrm{S}-18^{\circ} \mathrm{N}\right)$, Tropical Pacific $\left(18^{\circ} \mathrm{S}-18^{\circ} \mathrm{N}\right)$, Tropical Indian $\left(18^{\circ} \mathrm{S}-25^{\circ} \mathrm{N}\right)$, mid latitude Southern Ocean $\left(58^{\circ} \mathrm{S}-18^{\circ} \mathrm{S}\right)$, high latitude Southern Ocean $\left(>58^{\circ} \mathrm{S}\right)$.

the Revelle factor. The Revelle factor provides a convenient means to calculate changes in sea water chemistry, taking into account both the anthropogenic carbon uptake and change in the seawater physical state, such as temperature (Thomas et al., 2007; Egleston et al., 2010). It is computed as the change of $p \mathrm{CO}_{2}$ in seawater for a given change in surface concentration of dissolved inorganic carbon (DIC). Its value is indirectly proportional to atmospheric $\mathrm{CO}_{2}$ concentration and reversely proportional to the temperature of the seawater (Zeebe and Wolf-Gladrow, 2001). Therefore, given the same atmospheric $\mathrm{CO}_{2}$ concentration, relatively warm low latitude oceans generally have lower Revelle factors whereas colder high latitude oceans have higher Revelle factors (Sabine et al., 2004). This difference in temperature cause the DIC to vary, which in turn, indirectly alters the Revelle factor. As explained in literature (e.g., Mehrbach et al., 1973; Broecker and Peng, 1982), the change in temperature alter the dissociation constant of the chemistry reaction between the different carbon species (carbonic acid, bicarbonate, and carbonate), and therefore, perturbed the equilibrium between these species in seawater. Seawater with high (low) Revelle factor has low (high) buffer capacity of $\mathrm{CO}_{2}$ in the associated water mass. For this reason, seawater with low Revelle factor has a higher capacity in taking up anthropogenic $\mathrm{CO}_{2}$ from the atmosphere.

Future climate change is associated with raising temperature and atmospheric $\mathrm{CO}_{2}$ concentration. While higher sea surface temperature increase the buffer capacity, higher atmospheric $\mathrm{CO}_{2}$ does the opposite. It is a balance between these two factors that control the future oceanic buffer capacity, and hence the oceanic carbon uptake. Figure 9 shows the area-weighted regional evolution in the Revelle factor, estimated following Maier-Reimer and Hasselmann (1987). While Fig. 8 shows that the volcanic forcings alter the regional solubility of $\mathrm{CO}_{2}$ in seawater considerably, there is principally no change in the simulated Revelle factor (except for the Arctic). This suggests that on large scales, the ocean takes up approximately similar amount of carbon between the three volcanic experiments in this study. We note that while the Revelle factor is a useful indicator for estimating the ocean capacity in absorbing atmospheric $\mathrm{CO}_{2}$, it is important to keep in mind that the state of the ocean surface shown here is far from steady state, due to the transient state of the climate and atmospheric $\mathrm{CO}_{2}$.

With respect to the marine ecosystem, a global decrease in biological production is expected in the future. Under warmer climate, stronger stratification and shallower mixed layer depth would lead to reduced surface macro nutrients, essential for marine productivity (Bopp et al., 2001; Steinacher et al., 2010). Reduced marine production leads to reduced export production, which is a mechanism to transport carbon from surface to the deep water, also known as the "biological pump". By the end of the 21st century (i.e., averaged over 2090-2099), the REF run simulates a global export production of $8.0 \pm 0.2 \mathrm{PgC} \mathrm{yr}^{-1}$, considerably lower compare to the preindustrial value of $9.1 \pm 0.2 \mathrm{Pg} \mathrm{Cyr}^{-1}$. Experiments GEO_TAM25 and GEO_PIN25 produce similar quantities of $8.1 \pm 0.1$ and $8.1 \pm 0.2 \mathrm{PgC} \mathrm{yr}^{-1}$, respectively, 


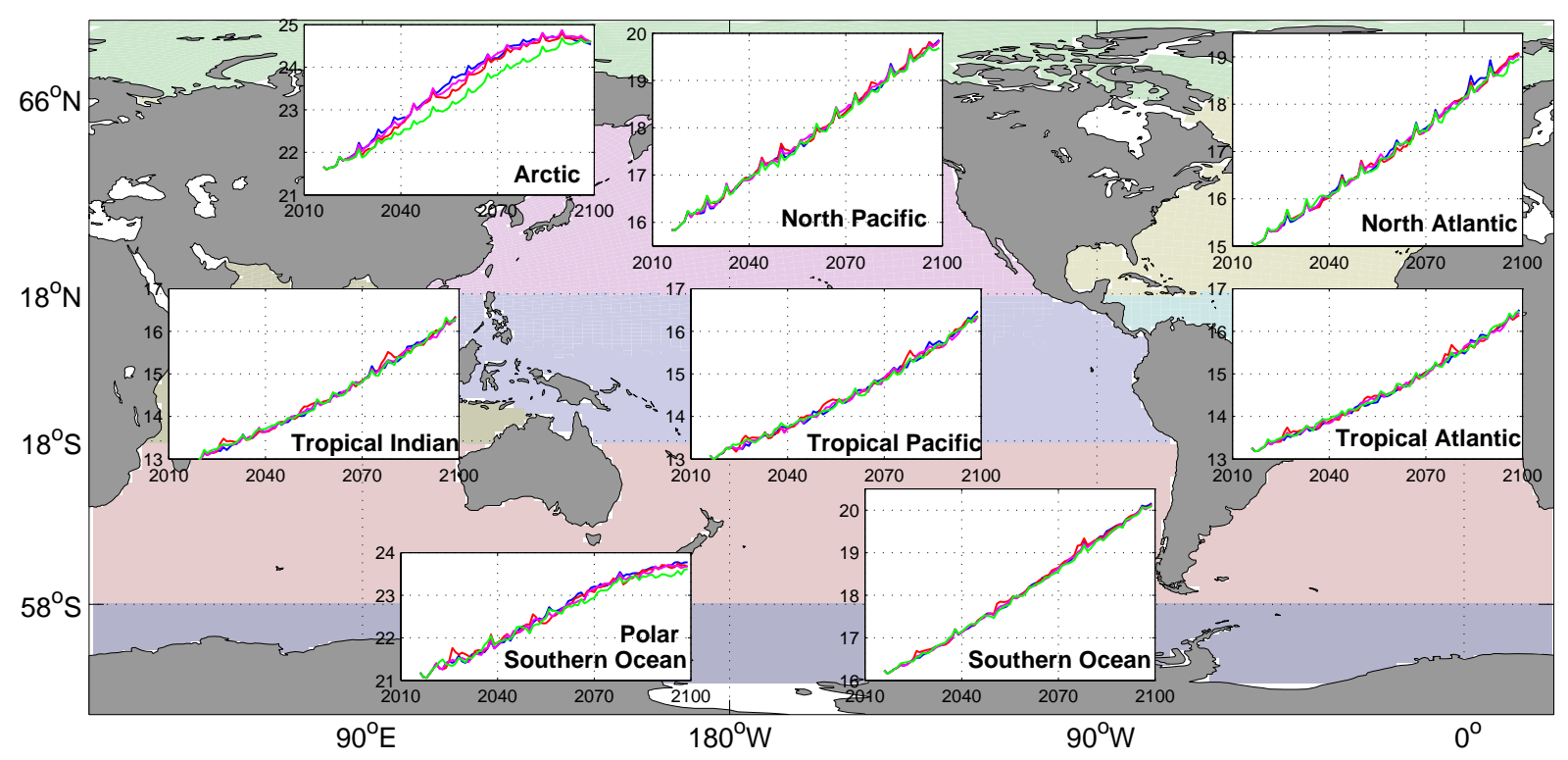

Fig. 9. Similar to Fig. 8 for the Revelle factor.

whereas GEO_PIN5 maintains a relatively higher export production of $8.7 \pm 0.3 \mathrm{PgC} \mathrm{yr}^{-1}$ at the end of this century, still within the preindustrial variability. Figure 10 shows Hovmöller diagrams of mean latitudinal differences in the annual export production between each of the perturbed simulations compared to the REF over the 2020-2099 period. The future reduction in the export production occurs predominantly at high latitudes, due to the simulated shallower mixed layer depth in this regions, consistent with the finding by Steinacher et al. (2010). However, the mixed layer depth reduction in the GEOPIN5 is relatively small compared to the GEO_TAM25 and GEO_PIN25, mainly due to the fact that GEO_PIN5 experience less SST warming (see also Fig. 4). As a result, the GEO_PIN5 run projects higher annual export production at the Northern and Southern Hemisphere high latitudes relative to the REF. In the polar latitude Southern Ocean, the signal is more difficult to interpret, which is attributed to the variations in the projected sea-ice in this regions. The pulse in the Equatorial regions could possibly be due to the impact of the volcanic forcings on the ENSO cycle. However, the experiment set up in this study is insufficient to draw any conclusions on how the different volcanic scenarios affect the future ENSO cycles.

Some studies have shown that the volcanic ash deposition could potentially lead to micro-nutrient fertilization (particularly iron) and enhance marine biological production locally following the short period after the volcanic event (Frogner et al., 2001; Jones and Gislason, 2008; Watson, 1997). However, a review paper by Duggen et al. (2010) indicates that the scientific community at present lacks a comprehensive understanding of the role of volcanic ash on the marine phytoplankton growth. In addition, difficulties regarding how to correctly model the volcanic dust impact on the marine production also arise from the diversity of particle dust compositions for the different volcanic sources and from the effects of volcanic dust on different phytoplankton species. Also, there are large uncertainties associated with the regional distribution of aerial volcanic dust deposition to the ocean, since this is highly dependent on the location of the eruption event. Finally, potential effects of other toxic trace metals associated with volcanic dust on various phytoplankton species remain poorly understood. Therefore, the analysis shown here simply represents the change in biological production that predominantly take place due to changes in the physical variability.

\section{Summary and discussion}

Future climate and carbon uptake are projected using the Bergen Earth system model under the SRES-A2 emission scenario. To study the potential feedback associated with episodic volcanic forcings within the 21 st century, multiple simulations were performed, applying three different scenarios of volcanic eruptions. In the first scenario, large volcanic eruptions, comparable to the 1815's Tambora, are prescribed for the year 2025, 2050, and 2075. On the second, slightly weaker eruptions comparable to the 1991's Pinatubo, are prescribed with the same frequency. On the third, the 1991's Pinatubo are prescribed with larger occurrence frequency of five-years, starting from year 2020.

The introduction of volcanic forcing into the future scenario leads to short term cooling in both the surface temperature as well as the SST. Figure 4 shows that the length of the 

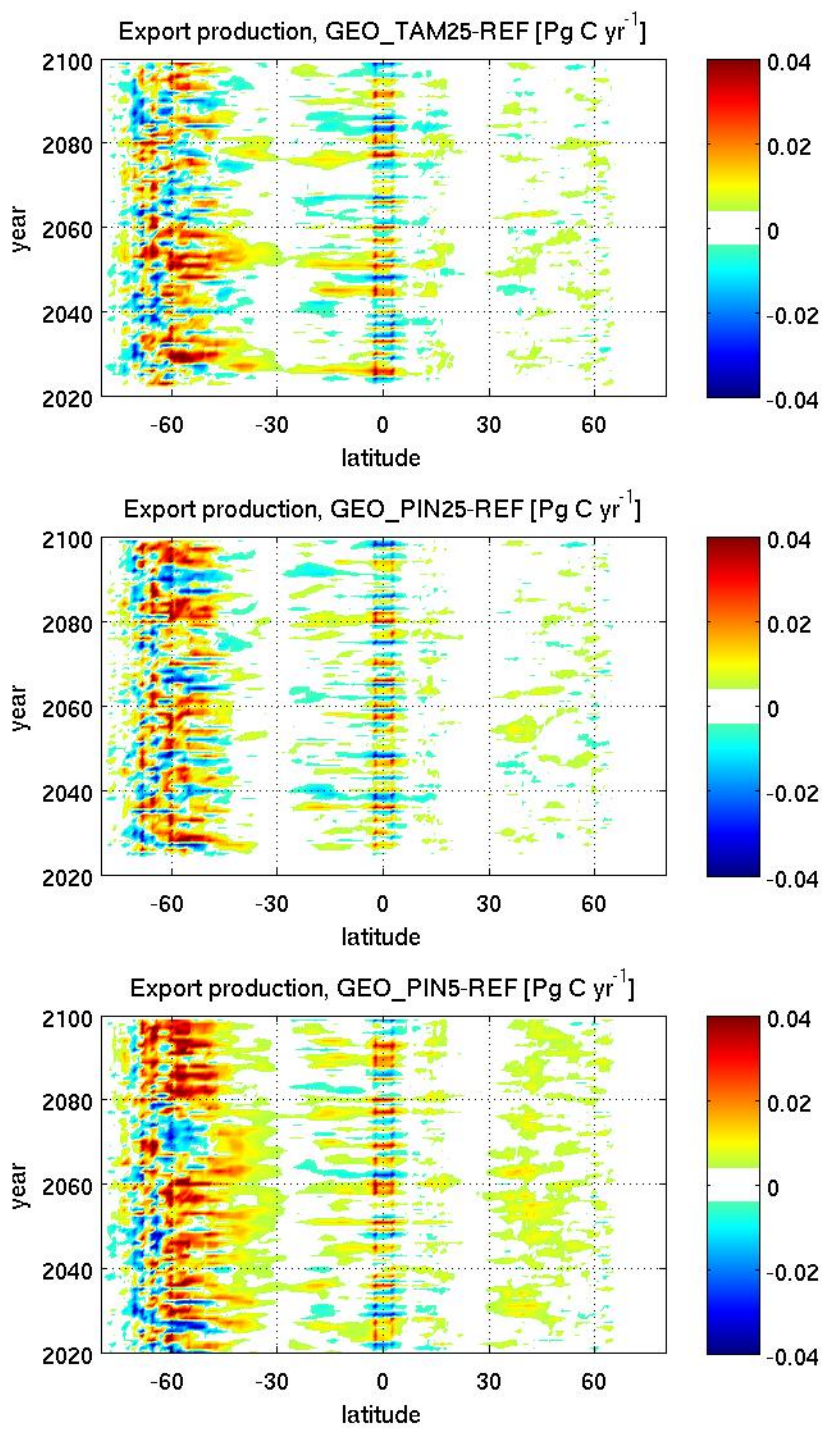

Fig. 10. Hovmöller diagrams of difference in annual marine export production between the three volcanic scenario simulations (GEO_TAM25, GEO_PIN25, GEO_PIN5) with the reference (REF) run for the 2020-2099 period.

temperature perturbation vary depending on the magnitude and frequency of volcanic forcings, predominantly by the latter. In addition, Wigley (2006) and Frölicher et al. (2011) also suggest that the recovery time of the temperature to the pre-eruption condition may vary between models depending on the climate sensitivity. We show that while aerosol loading indeed induce cooling to the global mean temperature, over a long period only an experiment with a high frequency of volcanic events simulates a long-lasting impact. For the preindustrial period, Frölicher et al. (2011) show that volcanic eruption could considerably alter the atmospheric $\mathrm{CO}_{2}$ concentration for up to several decades. However, we find that under business-as-usual future scenario, the background increase in atmospheric $\mathrm{CO}_{2}$ associated with the anthropogenic emissions would dominate.
For all experiments, there are positive feedbacks (i.e., more carbon uptake) on both the oceanic and terrestrial carbon reservoirs as a result of the volcanic forcings. Our experiments show that the feedback on the global carbon cycle is dominated by the terrestrial biosphere. Cooling over land leads to prolonged soil carbon turnover rate in midlatitude Northern Hemisphere and increased vegetation carbon budget at low latitudes, resulting in overall net carbon uptake. In some regions such as the polar Northern Hemisphere, the reduced soil respiration still prevails over the lowered photosynthesis rate. The enhanced carbon uptake by the land biosphere following a volcanic eruption is well supported by both modeling and inversion studies (Bousquet et al., 2000; Jones and Cox, 2001; Lucht et al., 2002; Brovkin et al., 2010) for the historical periods. Nevertheless, the regional uptake anomalies vary considerably between studies. For example, increased carbon content in the tropics is suggested by Jones and Cox (2001) and Brovkin et al. (2010), whereas the study by Bousquet et al. (2000) indicates more terrestrial carbon uptake in the Northern Hemisphere regions (e.g., north of $45^{\circ} \mathrm{N}$ ) due to eruption-induced cooling. Another study by Lucht et al. (2002), using a similar dynamical vegetation model as the BCM-C, also simulates highlatitude carbon uptake following the Pinatubo eruptions. Interestingly, the BCM-C simulates increased carbon content both in the tropics and Northern Hemisphere following the eruption events. We attribute this to the additional " $\mathrm{CO}_{2}$ fertilisation effect" induced in our model's future projections because the model does not simulate clear signals in the vegetation carbon content following the 1991 Mount Pinatubo eruption under the present day condition (see Fig. 3). Additionally, Tjiputra et al. (2010) have shown that the tropical terrestrial NPP in the BCM-C model is sensitive to an increase in atmospheric $\mathrm{CO}_{2}$. Thus the increase in the tropical vegetation carbon content shown in Fig. 7 is likely driven by the higher atmospheric $\mathrm{CO}_{2}$ concentrations simulated in the model future projections.

Over the ocean, the volcanic eruptions reduce the ocean heat content, and consequently lower the projected SST (Gregory, 2010). This condition favour stronger atmospheric $\mathrm{CO}_{2}$ uptake because the solubility of $\mathrm{CO}_{2}$ gas is higher in colder water, though the solubility effect is partly counteracted by a decrease in buffering ability at lower temperatures (i.e., under colder temperature, there are less occurring dissociation of carbonic acid into carbonate ion, which is important for buffering the dissolved $\mathrm{CO}_{2}$ at the ocean surface). In addition, simultaneous and stronger terrestrial carbon uptake lead to a reduction in atmospheric $\mathrm{CO}_{2}$, lowering the $p \mathrm{CO}_{2}$ gradient between the atmosphere and the ocean. On large-scales, all of these factors contribute to relatively small changes in the buffer capacity of the seawater, which resulted in small changes in long-term oceanic carbon uptake among the different experiments.

We show that while frequent and large volcanic eruptions in the future could counteract the anthropogenic global 
warming. This perturbation only last for a short term period until the background climate warming trend returns and come into effect. Our study indicates that geoengineering methods mimicking the volcanic eruptions would be in principle, and if no other reasons would speak against the procedure, reduce the anthropogenic climate change to some extent. The experiments also show that such methods could offer some benefits to the Earth system, such as by delaying the future warming rate, increasing anthropogenic carbon uptake, and slowing down the reduction in marine productivity. Nevertheless, there remain many unanticipated consequences that could lead to potentially catastrophic consequences. For example, the potential stratospheric ozone destruction, potential acid rain, effects on cirrus clouds, impacts of the released volcanic dust on terrestrial and marine ecosystem (Sarmiento, 1993; Duggen et al., 2010), and changes in regional atmospheric and ocean circulation that may need decades or centuries to recover (Jones et al., 2011). All of these factors remain poorly understood and the recent geoengineering studies (Matthews and Caldeira, 2007; Jones et al., 2010; Llanillo et al., 2010) include the warning that, should geoengineering fail or be stopped abruptly, it could lead to very rapid climate change, with warming rates up to 20 times greater than present-day rates. Even if such methods can be deployed successfully, our study suggests that a high concentration of atmospheric $\mathrm{CO}_{2}$ would remain in the atmosphere for a long time. Also, since our simulations do not produce considerable change in oceanic carbon uptake, the ocean could still be expected to acidify considerably by the end of the 21 st century.

There are also some caveats associated with the model used in this study. The ocean biogeochemistry model does not take into account any potential iron fertilization associated to the dust released by the volcanic eruptions (Duggen et al., 2010). The current version of the land carbon cycle model does not take into account change in diffuse light associated with changes in aerosol loadings. Mercado et al. (2009) show that changes in the cloud cover arising from volcanic eruptions alter the photosynthetically active radiation, hence the terrestrial carbon balance. The LPJ also does not implement nitrogen limitation, which could alter the carbon uptake due to climate change (Bonan and Levis, 2010).

Acknowledgements. We thank Christoph Heinze for the discussions and valuable feedbacks, Caroline Roelandt for reviewing the early version of the manuscript. We also thank Chris Jones and an anonymous referee for their thorough reviews and suggestions, which considerably improved the manuscript from its initial version. This study at the University of Bergen and Bjerknes Centre for Climate Research is supported by the Research Council of Norway funded project CarboSeason (grant no. 185105/S30), and the EU FP7 large-scale integrating projects CARBOCHANGE (grant no. 264879) and COMBINE (grant no. 226520). We acknowledge the Norwegian Metacenter for Computational Science and Storage Infrastructure (NOTUR and NorStore, "Biogeochemical Earth system modeling" project nn2980k and ns2980k) for providing the computing and storing resources essential for this study. This is publication no. A342 from the Bjerknes Centre for Climate Research.

Edited by: P. Friedlingstein

\section{References}

Angert, A., Biraud, S., Bonfils, C., Buermann, W., and Fung, I.: $\mathrm{CO}_{2}$ seasonality indicates origins of post-Pinatubo sink, Geophys. Res. Lett, 31, L11103, doi:10.1029/2004GL019760, 2004.

Bentsen, M., Drange, H., Furevik, T., and Zhou, T.: Simulated variability of the Atlantic meridional overturning circulation, Clim. Dynam., 22, 701-720, 2004.

Bleck, R. and Smith, L. T.: A wind-driven isopycnic coordinate model of the North and Equatorial Atlantic Ocean, 1. Model development and supporting experiments, J. Geophys. Res., 95, 3273-3285, 1990.

Bleck, R., Rooth, C., Hu, D., and Smith, L. T.: Salinity-driven Thermocline Transients in a Wind- and Thermohaline-forced Isopycnic Coordinate Model of the North Atlantic, J. Phys. Oceanogr., 22, 1486-1505, 1992.

Bonan, G. B. and Levis, S.: Quantifying carbon-nitrogen feedbacks in the community land model (CLM4), Geophys. Res. Lett., 37, L07401, doi:10.1029/2010GL042430, 2010.

Bopp, L., Monfray, P., Aumont, O., Dufresne, J.-L., Le Treut, H., Madec, G., Terray, L., and Orr, J. C.: Potential impact of climate change on marine export production, Global Biogeochem. Cy., 15, 81-99, 2001.

Bousquet, P., Peylin, P., Ciais, P., Le Quéré, C., Friedlingstein, P., and Tans, P. P.: Regional changes in carbon dioxide fluxes of land and oceans since 1980, Science, 290, 1342-1346, 2000.

Broecker, W. S. and Peng, T. H.: Tracers in the sea, Eldigio Press Lamont Doherty Geological Observatory, New York, 500-568, 1982.

Brovkin, V., Lorenz, S. J., Jungclaus, J., Raddatz, T., Timmreck, C., Reick, C. H., Segschneider, J., and Six, K.: Sensitivity of a coupled climate-carbon cycle model to large volcanic eruptions during the last millennium, Tellus B, 62, 674-681, 2010.

Crowley, T., Baum, S. K., Kim, K.-Y., Hegerl, G. C., and Hyde, W. T.: Modeling ocean heat content changes during the last millennium, Geophys. Res. Lett., 30, 1932, 2003.

Crueger, T., Roeckner, E., Raddatz, T., Schnur, R., and Wetzel, P.: Ocean dynamics determine the response of oceanic $\mathrm{CO}_{2}$ uptake to climate change, Clim. Dynam., 31, 151-168, doi:10.1007/s00382-007-0342-x, 2008.

Crutzen, P. J.: Albedo enhancement by stratospheric sulfur injections: a contribution to resolve a policy dilemma?, Climatic Change, 77, 211-219, 2006.

Duggen, S., Olgun, N., Croot, P., Hoffmann, L., Dietze, H., Delmelle, P., and Teschner, C.: The role of airborne volcanic ash for the surface ocean biogeochemical iron-cycle: a review, Biogeosciences, 7, 827-844, doi:10.5194/bg-7-827-2010, 2010.

Egleston, E. S., Sabine, C. L., and Morel, F. M. M.: Revelle revisited; Buffer factors that quantify the response of ocean chemistry to changes in DIC and alkalinity, Global Biogeochem. Cy., 24, GB1002, doi:10.1029/2008GB003407, 2010. 
Frank, D. C., Esper, J., Raible, C. C., Büntgen, U., Trouet, V., Stocker, B., and Joos, F.: Ensemble reconstruction constraints on the global carbon cycle sensitivity to climate, Nature, 463, 527-530, doi:10.1038/nature08769, 2010.

Friedlingstein, P., Cox, P., Betts, R., Bopp, L., von Bloh, W., Brovkin, V., Cadule, P., Doney, S., Eby, M., Fung, I., Gala, B., John, J., Jones, C., Joos, F., Kato, T., Kawamiya, M., Knorr, W., Lindsay, K., Matthews, H. D., Raddatz, T., Rayner, P., Reick, C., Roeckner, E., Schnitzler, K.-G., Schnur, R., Strassmann, K., Weaver, A. J., Yoshikawa, C., and Zeng, N.: Climate-carbon cycle feedback analysis: Results from the $\mathrm{C}^{4} \mathrm{MIP}$ model intercomparison, J. Climate, 19, 3337-3353, 2006.

Frölicher, T. L., Joos, F., and Raible, C. C.: Sensitivity of atmospheric $\mathrm{CO}_{2}$ and climate to explosive volcanic eruptions, Biogeosciences Discuss., 8, 2957-3007, doi:10.5194/bgd-8-29572011, 2011.

Frogner, P., Gíslason, S. R., and Óskarsson, N.: Fertilizing potential of volcanic ash in ocean surface water, Geology, 29, 487-490, 2001.

Furevik, T., Bentsen, M., Drange, H., Kindem, I. K. T., Kvamst $\varnothing$, N. G., and Sorteberg, A.: Description and evaluation of the Bergen climate model: ARPEGE coupled with MICOM, Clim. Dynam., 21, 27-51, doi:10.1007/s00382-003-0317-5, 2003.

Gerber, S., Joos, F., Brügger, P. P., Stocker, T. F., Mann, M. E., Sitch, S., and Scholze, M.: Constraining temperature variations over the last millennium by comparing simulated and observed atmospheric $\mathrm{CO}_{2}$, Clim. Dynam., 20, 281-299, doi:10.1007/s00382-002-0270-8, 2003.

Gloor, M., Sarmiento, J. L., and Gruber, N.: What can be learned about carbon cycle climate feedbacks from the $\mathrm{CO}_{2}$ airborne fraction?, Atmos. Chem. Phys., 10, 7739-7751, doi:10.5194/acp-10-7739-2010, 2010.

Gregory, J. M.: Long-term effect of volcanic forcing on ocean heat content, Geophys. Res. Lett., 37, L22701, doi:10.1029/2010GL045507, 2010.

Hansen, J., Sato, M., Ruedy, R., Lacis, A., Asamoah, K., Borenstein, S., Brown, E., Cairns, B., Caliri, G., Campbell, M., Curran, B., de Castro, S., Druyan, L., Fox, M., Johnson, C., Lerner, J., McCormick, M. P., Miller, R. L., Minnis, P., Morrison, A., Pandolfo, L., Ramberran, I., Zaucker, F., Robinson, M., Russell, P., Shah, K., Stone, P., Tegen, I., Thomason, L., Wilder, J., and Wilson, H.: A Pinatubo climate modeling investigation, in: The Mount Pinatubo eruption: Effects on the atmosphere and climate, edited by: Fiocco, G., Fua, D., and Visconti, G., NATO ASI Series, Ser. I, 42, 219-231, 1996.

Houghton, R. A. and Hackler, J. L.: Carbon flux to the atmosphere from land-use changes, Trends: A compendium of data on global change, Carbon Dioxide Information Analysis Center, US Department of Energy, Oak Ridge, TN, USA, 2002.

Jones, A., Haywood, J., and Boucher, O.: Climate impacts of geoengineering marine stratocumulus clouds, J. Geophys. Res., 114, D10106, doi:10.1029/2008JD011450, 2009.

Jones, A., Haywood, J., Boucher, O., Kravitz, B., and Robock, A.: Geoengineering by stratospheric $\mathrm{SO}_{2}$ injection: results from the Met Office HadGEM2 climate model and comparison with the Goddard Institute for Space Studies ModelE, Atmos. Chem. Phys., 10, 5999-6006, doi:10.5194/acp-10-5999-2010, 2010.
Jones, A., Haywood, J., and Boucher, O.: A comparison of the climate impacts of geoengineering by stratospheric $\mathrm{SO}_{2}$ injection and by brightening of marine stratocumulus cloud, Atmos. Sci. Lett., 12, 176-183, doi:10.1002/as1.291, 2011.

Jones, C. D. and Cox, P. M.: Modeling the volcanic signal in the atmospheric $\mathrm{CO}_{2}$ record, Global Biogeochem. Cy., 15, 453-465, 2001.

Jones, M. T. and Gislason, S. R.: Rapid releases of metal salts and nutrients following the deposition of volcanic ash into aqueous environments, Geochim. Cosmochim. Acta, 72, 3661-3680, 2008.

Le Quéré, C., Raupach, M. R., Canadell, J. G., Marland, G., Bopp, L., Ciais, P., Conway, T. J., Doney, S. C., Feely, R., Foster, P., Friedlingstein, P., Gurney, K., Houghton, R. A., House, J. I., Huntingford, C., Levy, P. E., Lomas, M. R., Majkut, J., Metzl, N., Ometto, J. P., Peters, G. P., Prentice, I. C., Randerson, J. T., Running, S. W., Sarmiento, J. L., Schuster, U., Sitch, S., Viovy, T. T. N., van der Werf, G. R., and Woodward, F. I.: Trends in the sources and sinks of carbon dioxide, Nat. Geosci., 2, 831-836, doi:10.1038/ngeo689, 2009.

Llanillo, P., Jones, P. D., and von Glasow, R.: The influence of stratospheric sulphate aerosol deployment on the surface air temperature and the risk of an abrupt global warming, Atmosphere, 1(1), 62-84, doi:10.3390/atmos1010062, 2010.

Lucht, W., Prentice, I. C., Myneni, R. B., Sitch, S., Friedlingstein, P., Cramer, W., Bousquet, P., Buermann, W., and Smith, B.: Climate control of the high-latitude vegetation greening trend and Pinatubo effect, Science, 296, 1687-1689, 2002.

Maier-Reimer, E. and Hasselmann, K.: Transport and storage of $\mathrm{CO}_{2}$ in the ocean-an inorganic ocean-circulation carbon cycle model, Clim. Dynam., 2, 63-90, 1987.

Maier-Reimer, E., Kriest, I., Segschneider, J., and Wetzel, P.: The HAMburg Ocean Carbon Cycle Model HAMOCC5.1 Technical Description Release 1.1, Berichte zur Erdsystemforschung 14, ISSN 1614-1199, Max Planck Institute for Meteorology, Hamburg, Germany, 50 pp., 2005.

Marland, G., Boden, T. A., and Andres, R. J.: Global, regional, and national $\mathrm{CO}_{2}$ emissions, Trends: $\mathrm{A}$ compendium of data on global change, Carbon Dioxide Information Analysis Center, US Department of Energy, Oak Ridge, TN, USA, 2005.

Matthews, H. D. and Caldeira, K.: Transient climate-carbon simulations of planetary geoengineering, P. Natl Acad. Sci. USA, 104, 9949-9954, doi:10.1073/pnas.0700419104, 2007.

Meehl, G. A., Stocker, T. F., Collins, W. D., Friedlingstein, P., Gaye, A. T., Gregory, J. M., Kitoh, A., Knutti, R., Murphy, J. M., Noda, A., Raper, S. C. B., Watterson, I. G., Weaver, A. J., and Zhao, Z.-C.: Global climate projections, in: Climate Change 2007: The Physical Science Basis. Contribution of Working Group I to the Fourth Assessment Report of the Intergovernmental Panel on Climate Change, edited by: Solomon, S., Qin, D., Manning, M., Chen, Z., Marquis, M., Averyt, K. B., Tignor, M., and Miller, H. L., Cambridge University Press, Cambridge, UK and New York, NY, USA, 747-845, 2007.

Mehrbach, C., Culberson, C. H., Hawley, J. E., and Pytkowicz, R. M.: Measurement of the apparent dissociation constants of carbonic acid in seawater at atmospheric pressure, Limnol. Oceanogr., 18, 897-907, 1973. 
Mercado, L. M., Bellouin, N., Sitch, S., Boucher, O., Huntingford, C., Wild, M., and Cox, P. M.: Impact of changes in diffuse radiation on the global land carbon sink, Nature, 458, 1014-1017, doi:10.1038/nature07949, 2009.

Moore, J. C., Jevrejeva, S., and Grinsted, A.: Efficacy of geoengineering to limit 21 st century sea-level rise, P. Natl. Acad. Sci. USA, 107(36), 15699-15703, doi:10.1073/pnas.1008153107, 2010.

Otterå, O. H.: Simulating the effects of the 1991 Mount Pinatubo volcanic eruption using the ARPEGE atmosphere general circulation model, Adv. Atmos. Sci., 25, 213-226, 2008.

Otterå, O. H., Bentsen, M., Bethke, I., and Kvamstø, N. G.: Simulated pre-industrial climate in Bergen Climate Model (version 2): model description and large-scale circulation features, Geosci. Model Dev., 2, 197-212, doi:10.5194/gmd-2-197-2009, 2009.

Otterå, O. H., Bentsen, M., Drange, H., and Suo, L.: External forcing as a metronome for Atlantic multidecadal variability, Nat. Geosci., 3, 688-694, doi:10.1038/ngeo955, 2010.

Rasch, P. J., Tilmes, S., Turco, R. P., Robock, A., Oman, L., Chen, C. C., Stenchikov, G. L., and Garcia, R. R.: An overview of geoengineering of climate using stratospheric sulphate aerosols, Philos. T. Roy. Soc. A, 366, 4007-4037, 2008.

Robock, A.: Volcanic eruptions and climate, Rev. Geophys., 38, 191-219, 2000.

Robock, A., Oman, L., and Stenchikov, G. L.: Regional climate responses to geoengineering with tropical and Arctic $\mathrm{SO}_{2}$ injections, J. Geophys. Res., 113, D16101, doi:10.1029/2008JD010050, 2008.

Robock, A., Bunzl, M., Kravitz, B., and Stenchikov, G. L.: A test for geoengineering?, Science, 327, 530-531,, 2010.

Royal Society: Geoengineering the climate, Policy Report 09/09, Royal Society, London, 2009.

Sabine, C. L., Feely, R. A., Gruber, N., Key, R. M., Lee, K., Bullister, J. L., Wanninkhof, R., Wong, C. S., Wallace, D. W. R., Tilbrook, B., Millero, F. J., Peng, T.-H., Kozyr, A., Ono, T., and Rios, A. F.: The oceanic sink for anthropogenic $\mathrm{CO}_{2}$, Science, 305, 367-371, 2004.

Sarmiento, J. L.: Atmospheric $\mathrm{CO}_{2}$ stalled, Nature, 365, 697-698, 1993.
Sarmiento, J. L., Gloor, M., Gruber, N., Beaulieu, C., Jacobson, A. R., Mikaloff Fletcher, S. E., Pacala, S., and Rodgers, K.: Trends and regional distributions of land and ocean carbon sinks, Biogeosciences, 7, 2351-2367, doi:10.5194/bg-7-2351-2010, 2010.

Sitch, S., Smith, B., Prentice, I. C., Arneth, A., Bondeau, A., Cramer, W., Kaplan, J. O., Levis, S., Lucht, W., Sykes, M. T., Thonicke, K., and Venevsky, S.: Evaluation of ecosystem dynamics, plant geography and terrestrial carbon cycling in the LPJ dynamic global vegetation model, Global Change Biol., 9, 161$185,2003$.

Steinacher, M., Joos, F., Frölicher, T. L., Bopp, L., Cadule, P., Cocco, V., Doney, S. C., Gehlen, M., Lindsay, K., Moore, J. K., Schneider, B., and Segschneider, J.: Projected 21st century decrease in marine productivity: a multi-model analysis, Biogeosciences, 7, 979-1005, doi:10.5194/bg-7-979-2010, 2010.

Stenchikov, G., Delworth, T. L., Ramaswamy, V., Stouffer, R. J., Wittenberg, A., and Zeng, F.: Volcanic signals in oceans, J. Geophys. Res., 114, D16104, doi:10.1029/2008JD011673, 2009.

Thomas, H., Friederike Prowe, A. E., van Heuven, S., Bozec, Y., de Baar, H. J. W., Schiettecatte, L.-S., Suykens, K., Koné, M., Borges, A. V., Lima, I. D., and Doney, S. C.: Rapid decline of the $\mathrm{CO}_{2}$ buffering capacity in the North Sea and implications for the North Atlantic Ocean, Global Biogeochem. Cy., 21, GB4001, doi:10.1029/2006GB002825, 2007.

Tjiputra, J. F., Assmann, K., Bentsen, M., Bethke, I., Otterå, O. H., Sturm, C., and Heinze, C.: Bergen Earth system model (BCM-C): model description and regional climate-carbon cycle feedbacks assessment, Geosci. Model Dev., 3, 123-141, doi:10.5194/gmd-3-123-2010, 2010.

Wanninkhof, R.: Relationship between wind speed and gas exchange over the ocean, J. Geophys. Res., 97, 7373-7382, 1992.

Watson, A.: Volcanic iron, $\mathrm{CO}_{2}$, ocean productivity and climate, Nature, 385, 587-588, doi:10.1038/385587b0, 1997.

Wigley, T. M. L.: A combined mitigation/geoengineering approach to climate stabilization, Science, 314, 452-545, 2006.

Zeebe, R. E. and Wolf-Gladrow, D. E.: $\mathrm{CO}_{2}$ in seawater: Equilibrium, Kinetics, Isotops, Elsevier Oceanography Series, Amsterdam, The Netherlands, 65, 346 pp., 2001. 